\title{
Effects of carob (Ceratonia siliqua) pod byproduct on quail performance, egg characteristics, fatty acids, and cholesterol levels
}

\author{
Suleyman Calislar ${ }^{1 *}$, Yusuf Kaplan ${ }^{1}$ \\ ${ }^{1}$ Kahramanmaraş Sutcu Imam University, Faculty of Agriculture, Department of Animal Science, Kahramanmaraş, Turkey.
}

ABSTRACT - This study was carried out to determine the effects of a carob (Ceratonia siliqua) byproduct (CB) supplement in diets for laying Japanese quail (Coturnix coturnix japonica) on performance and egg internal-external quality traits, fatty acid profile, and cholesterol content. A total of 225 female quail at 12 weeks of age were distributed into five treatment groups with three replications (15 birds in each replication). The following treatments were tested: $0 \%$ (control, no $\mathrm{CB}$ supplementation); $3 \% \mathrm{CB} ; 5 \% \mathrm{CB} ; 10 \% \mathrm{CB}$; and $15 \% \mathrm{CB}$ in the diets. Feed and water were provided ad libitum to quail. The lighting program was $16 \mathrm{~h}$ light and $8 \mathrm{~h}$ dark. The experiment lasted 60 days. Treatments had no significant effects on final weight, feed intake, feed conversion ratio, egg production, and mortality. The external egg quality characteristics, shape index, shell weight, shell thickness, albumen index, yolk index, yolk weight, yolk fat, yolk color, yolk cholesterol, stearic acid, oleic acid, and heptadecanoic acid concentrations were not significantly influenced by CB supplementation to quail diets. Haugh unit, egg yolk total saturated fatty acids, total mono or polyunsaturated fatty acids, linoleic acid, gamma linolenic acid, palmitic, and palmitoleic acid contents were significantly influenced by the treatments. Carob byproduct can be used up to $15 \%$ in laying quail diets without any negative effects on performance, mortality, or internal egg quality traits.

Key Words: egg yolk, fatty acid profiles, Japanese quail, locust bean pod byproduct, production parameters

\section{Introduction}

Carob (Ceratonia siliqua) growing has been performed in the Mediterranean region for about 4,000 years. The world annual carob production is estimated at $310,000 \mathrm{t}$ from approximately 200,000 ha (Makris and Kefalas, 2004). In Turkey, annual carob production is approximately $13,500 \mathrm{t}$, obtained from 354,000 carob trees (Biner et al., 2007).

The carob seed contains approximately $40.8 \mathrm{mg} \mathrm{g}^{-1}$ total phenol, $16.2 \mathrm{mg} \mathrm{g}^{-1}$ condensed tannins, and $2.98 \mathrm{mg} \mathrm{g}^{-1}$ hydrolyzed tannins (Avallone et al., 1997). The sugar content in the carob fruit varies between 48 and $72 \%$ and the fruit is an important source of phenols, which have significant

Received: May 8, 2016

Accepted: October 5, 2016

*Corresponding author: scalislar@ksu.edu.tr http://dx.doi.org/10.1590/S1806-92902017000200005

How to cite: Calislar, S. and Kaplan, Y. 2017. Effects of carob (Ceratonia siliqua) pod byproduct on quail performance, egg characteristics, fatty acids, and cholesterol levels. Revista Brasileira de Zootecnia 46(2):113-117.

Copyright (c) 2017 Sociedade Brasileira de Zootecnia. This is an Open Access article distributed under the terms of the Creative Commons Attribution License (http://creativecommons.org/licenses/by/4.0/), which permits unrestricted use, distribution, and reproduction in any medium, provided the original work is properly cited. antioxidant powers (Makris and Kefalas, 2004). Carobs have a gum content of 42 to $46 \%$, mostly composed of natural galactomannan (Saura-Calixto, 1987).

Carob contains phenolic compounds such as gallic, syringic, and sinapic acid, being gallic acid the most abundant (1,550 $\mathrm{mg} \mathrm{g}^{-1}$ dry matter) (Ayaz et al., 2007). Carob is also rich in C18:1n-9 and C18:2n-6 fatty acids and contains $0.1041 \mathrm{mg} \mathrm{g}^{-1}$ vitamin C (Gubbuk et al., 2010). However, carob byproducts have a high cellulose content and, therefore, they are restricted to up to $20 \%$ in poultry diets (Göhl, 1982). Nevertheless, supplementation of 6-9\% of this ingredient in poultry diets may cause a decrease in protein and fat digestibility (13-30\%) and an increase in jejunal sticky digesta (Ortiz et al., 2004). The apparent metabolic energy in geese was reported as $6.1 \mathrm{MJ} / \mathrm{kg}$ and the actual metabolizable energy as $6.6 \mathrm{MJ} / \mathrm{kg}$. In goose diets, supplements up to $20 \%$ did not influence body weight, although $30 \%$ decreased both body weight and feed conversion ratio. Increasing carob pod ratios in diets decreased intestine (small, large, and caecum) length and gizzard weight in geese (Sahle et al., 1992).

The present study was conducted to investigate the effects of carob pod supplement in quail diets on performance and egg internal-external quality traits, fatty acid profile, and cholesterol content. 


\section{Material and Methods}

The experiment was conducted in Kahramanmaraş Province, Turkey. A total of 225 twelve-week-old female Japanese quail (Coturnix coturnix japonica) were distributed into five treatment groups with three replications of 15 birds each. Treatments were arranged as follows: $0 \%$ (control, no carob byproduct (CB) supplementation); 3\% CB; $5 \%$ CB; $10 \% \mathrm{CB}$; and $15 \% \mathrm{CB}$ in the diets. Feed and water were provided ad libitum to quail. The lighting program was set as $16 \mathrm{~h}$ light and $8 \mathrm{~h}$ dark. The experiment lasted 60 days.

Individual body weights of quail were determined at the beginning and end of the trial. Feed intake and feed conversion ratio of groups were determined weekly. Egg mass was calculated for the same week using egg weights and egg production rates (\%). Daily egg production was recorded. Egg weight, egg internal and external quality traits (yolk weight, yolk color, Haugh unit, albumen index, yolk index, shape index, shell thickness, and shell weight), and egg yolk cholesterol were determined in the last week of the study. Mortality was recorded daily.

Feed dry matter, crude protein (\%) (total $\mathrm{N}$ in samples $\times 6.25)$, crude fat (\%), crude ash (\%), and crude fiber (\%) analyses were carried out according to AOAC (2005). Starch content was determined by the polarimetric method, according to Karabulut and Canbolat (2005). Total sugar content was determined through the method described by Dubois et al. (1956). The metabolizable energy value of $\mathrm{CB}$ used in the diets $(\mathrm{kcal} / \mathrm{kg})$ was calculated as follows: $\mathrm{ME}=239 \times[(0.1551 \times$ crude protein $)+(0.1669 \times$ starch $)+$ $(0.3431$ crude fat $)+(0.13 \times$ sugar $)]($ Hartel, 1986$)($ Tables 1 and 2).

In the egg yolk, fatty acid composition was determined according to IUPAC IID19 (IUPAC, 1987). To determine yolk cholesterol levels, the egg was boiled in water and then the yolk was separated and homogenized. From these samples, $0.1 \mathrm{~g}$ was placed in a glass tube and mixed with $4 \mathrm{~mL}$ isopropyl alcohol (99.5\% pure) and then read at a 520 -nm wavelength in a spectrophotometer (Spectra Max plus 384); the amount of cholesterol in the egg yolks was calculated using a formula proposed by Boehringer Mannheim Gmbh Biochemica (1989).

Data were analyzed by the one-way ANOVA under the general linear model procedure of SAS computer software (Statistical Analysis System, version 9.1). The model included the CB level of diets. Means were separated using Duncan's multiple range tests. The results of statistical analysis were shown as mean values and standard error of the mean in the tables. Statistical significance was considered at $\mathrm{P}<0.05$.
Table 1 - Analyzed nutrient content of carob pod byproducts

\begin{tabular}{lc}
\hline Nutrient & Amount (\%) \\
\hline Dry matter & 86.5 \\
Crude protein & 4.0 \\
Crude fat & 0.83 \\
Crude ash & 3.0 \\
Starch & 5.7 \\
Sugar & 37.5 \\
Crude fiber & 9.66 \\
Calcium & 0.34 \\
Total phosphorus & 0.089 \\
Metabolic energy $(\mathrm{MJ} / \mathrm{kg})^{1}$ & 6.735 \\
\hline
\end{tabular}

${ }^{1}$ Metabolic energy was calculated according to Hartel (1986).

Table 2 - Composition and nutrient content of diets used in the experiment

\begin{tabular}{|c|c|c|c|c|c|}
\hline \multirow{2}{*}{ Ingredient $(\%)$} & \multicolumn{5}{|c|}{ Carob pod byproduct level (\%) } \\
\hline & 0 & 3 & 5 & 10 & 15 \\
\hline Maize & 46.58 & 40.76 & 37.20 & 30.30 & 24.14 \\
\hline Full fat soybean & 11.00 & 19.44 & 24.30 & 25.00 & 21.96 \\
\hline Soybean seed meal & 25.00 & 18.38 & 15.00 & 16.30 & 20.36 \\
\hline Sunflower seed meal & 4.10 & 5.00 & 5.00 & 3.40 & 2.00 \\
\hline Carob pod byproduct & 0.00 & 3.00 & 5.00 & 10.00 & 15.00 \\
\hline Soybean oil & 4.50 & 4.70 & 4.83 & 6.20 & 7.86 \\
\hline Dicalcium phosphate & 1.18 & 1.22 & 1.16 & 1.28 & 1.38 \\
\hline Limestone & 7.10 & 6.96 & 6.98 & 6.97 & 6.74 \\
\hline Methionine & 0.09 & 0.09 & 0.08 & 0.10 & 0.11 \\
\hline Common salt & 0.20 & 0.20 & 0.20 & 0.20 & 0.20 \\
\hline Vitamin + mineral premix ${ }^{1}$ & 0.25 & 0.25 & 0.25 & 0.25 & 0.25 \\
\hline Total (kg) & 100 & 100 & 100 & 100 & 100 \\
\hline \multicolumn{6}{|l|}{ Calculated nutrient composition } \\
\hline Dry matter (\%) & 90.97 & 90.80 & 90.69 & 90.62 & 90.60 \\
\hline Crude protein (\%) & 20.5 & 20.5 & 20.5 & 20.5 & 20.5 \\
\hline Crude fat $(\%)$ & 8.43 & 9.98 & 10.87 & 12.08 & 12.90 \\
\hline Crude ash (\%) & 10.21 & 10.11 & 10.14 & 10.16 & 9.98 \\
\hline Crude fiber $(\%)$ & 3.59 & 3.93 & 4.06 & 4.19 & 4.37 \\
\hline Calcium $(\%)^{2}$ & 3.02 & 2.99 & 3.00 & 3.04 & 2.99 \\
\hline Total phosphorus $(\%)^{2}$ & 0.60 & 0.59 & 0.60 & 0.60 & 0.60 \\
\hline Available phosphorus $(\%)^{2}$ & 0.34 & 0.34 & 0.33 & 0.32 & 0.32 \\
\hline Lysine $(\%)^{2}$ & 1.11 & 1.11 & 1.11 & 1.14 & 1.16 \\
\hline Methionine $(\%)^{2}$ & 0.43 & 0.43 & 0.43 & 0.43 & 0.43 \\
\hline Metabolizable energy $(\mathrm{MJ} / \mathrm{kg})^{3}$ & 11.69 & 11.69 & 11.69 & 11.69 & 11.69 \\
\hline \multicolumn{6}{|c|}{$\begin{array}{l}{ }^{1} \text { Each } \mathrm{kg} \text { of diet contained: vitamin } \mathrm{A}, 12.000 \mathrm{IU} \text {; vitamin D3, } 2000 \mathrm{IU} \text {; vitamin E, } 35 \mathrm{mg} \text {; } \\
\text { vitamin } \mathrm{K}_{3}, 5 \mathrm{IU} \text {; vitamin } \mathrm{B}_{1}, 3 \mathrm{mg} \text {; vitamin } \mathrm{B}_{2}, 6 \mathrm{mg} \text {; vitamin } \mathrm{B}_{6}, 5 \mathrm{mg} \text {; vitamin } \\
\mathrm{B}_{12}, 0.015 \mathrm{mg} \text {; vitamin } \mathrm{C}, 50 \mathrm{mg} \text {; D-biotin, } 0.045 \mathrm{mg} \text {; niacin, } 20 \mathrm{mg} \text {; calcium D } \\
\text { pantothenate, } 6 \mathrm{mg} \text {; folic acid, } 0.75 \mathrm{mg} \text {; choline chloride, } 12.5 \mathrm{mg} \text {; manganese, } 80 \mathrm{mg} \text {; } \\
\text { iron, } 60 \mathrm{mg} \text {; zinc, } 60 \mathrm{mg} \text {; copper, } 5 \mathrm{mg} \text {; iodine, } 1 \mathrm{mg} \text {; cobalt, } 0.2 \mathrm{mg} \text {; selenium, } 0.15 \mathrm{mg} \text {; } \\
\text { canthaxanthin, } 15 \mathrm{mg} \text {; and } \text {-apo- } 8 \text {-carotenoic acid ethyl ester, } 5 \mathrm{mg} \text {. } \\
{ }^{2} \text { Calculated according to NRC (1994). } \\
{ }^{3} \text { Calculated according to Hartel (1986). }\end{array}$} \\
\hline
\end{tabular}

\section{Results and Discussion}

There were no significant differences among the treatment groups in terms of final weight. There were no significant differences among the treated groups with regard to feed intake. The carob byproduct contains high levels of tannins (Alumot et al., 2006; Karabulut et al., 2006), which can reduce feed intake and body weight of goat kid (Silanikove et al., 2006). The sweet taste of the CB 
supplement may result in higher feed intake (Silanikove et al., 2006; Kotrotsios et al., 2010). In the current experiment, quail fed supplemented diets consumed more feed than the control group and this increased feed intake may have been a result of the sweet taste of the CB supplement (Table 3).

No significant differences were observed in feed conversion ratio of the treated groups. This result was similar to the report of Ylldırım and Kaya (2011), in which ground CB supplement in broiler diets did not affect feed conversion ratio of broiler at 28 to 35 days of age. The pulp of the CB also contains significant amount of tannin. The tannins in CB have a detrimental effect on the growth of goat kid; however, they have triglycerides and a cholesterollowering effect in blood (Silanikove et al., 2006). Yıldırım and Kaya (2011) determined that supplementation of 0,5 , 10 , and $20 \% \mathrm{CB}$ decreased body weight gain, but increased feed intake and feed conversion ratio of broilers. In another experiment (Sahle et al., 1992), despite the increase in feed intake of broiler and geese fed diets supplemented with carob, there was no decline in body weight or feed conversion ratio. There was no significant difference among treatments in terms of mortality rate (Table 3 ).

Table 3 - Some performance values and mortality of quail fed diets containing different levels of carob pod byproduct

\begin{tabular}{|c|c|c|c|c|c|c|c|}
\hline \multirow{2}{*}{ Parameter } & \multicolumn{5}{|c|}{ Carob pod byproduct level (\%) } & \multirow{2}{*}{ - SEM } & \multirow{2}{*}{ P-value } \\
\hline & 0 & 3 & 5 & 10 & 15 & & \\
\hline Initial weight (g) & 263.6 & 263.4 & 265.3 & 265.1 & 263.6 & 16.25 & 0.95 \\
\hline Final weight $(\mathrm{g})$ & 270.3 & 268.3 & 265.4 & 266.5 & 265.8 & 36.57 & 0.84 \\
\hline Feed intake $(\mathrm{g})$ & 40.47 & 42.12 & 40.01 & 43.15 & 41.74 & 2.68 & 0.20 \\
\hline Feed conversion ratio & 3.30 & 3.28 & 3.16 & 3.47 & 3.20 & 0.01 & 0.09 \\
\hline Mortality (\%) & 8.89 & 8.89 & 6.67 & 6.67 & 6.67 & 4.44 & 0.58 \\
\hline
\end{tabular}

SEM - standard error of the mean.
The treatments did not have significant effects on egg production, cholesterol contents, external and internal egg characteristics such as egg weight, eggshell weight, thickness, albumen index, yolk index, egg shape index, egg yolk color, egg yolk weight, and yolk fat in the overall experimental period $(\mathrm{P}>0.05)$. On the other hand, Haugh unit values of control and 3\% CB-supplemented groups were lower than those of the other CB-supplemented groups $(\mathrm{P}<0.05)$ (Table 4). However, Silanikove et al. (2006) noted that CB contains condensed tannins, which may bind the dietary lipids in the gastro intestine and cause a hypocholesterolemic effect on the body. Perez-Olleros et al. (1999) reported that CB is rich in cellulose, which may reduce total cholesterol and low-density lipoprotein in laboratory animals. This was not the case in the current experiment.

There were no differences among groups in terms of yolk palmitic acid (C16:0), heptadecanoic acid (C17:0), stearic acid (C18:0), oleic acid (C18:1), and total unsaturated fatty acid concentrations (Table 5). Although there was a tendency of decrease in palmitic acid (C16:0), stearic acid and oleic acid (C18:1) concentrations in egg yolk with increasing $\mathrm{CB}$ supplementation, this decrease was not significant. A similar trend was observed in total saturated fatty acid and total monounsaturated content of egg yolk $(\mathrm{P}<0.05)$. In addition, the palmitoleic acid (C16:1) concentration decreased with increasing $\mathrm{CB}$ supplementation ratios in diets and palmitoleic acid content of CB-supplemented groups was significantly lower than that of the control group.

The treatment had a significant $(\mathrm{P}<0.05)$ effect on the linoleic acid content of yolk. The increase in linoleic acid of yolk is possibly associated with $\mathrm{CB}$ and soybean oil, which are very rich in linoleic acid (Gubbuk et al., 2010).

Table 4 - Some egg quality traits and yolk cholesterol content of quail fed different diets containing carob pod byproduct

\begin{tabular}{|c|c|c|c|c|c|c|c|c|}
\hline \multirow{2}{*}{ Parameter } & \multirow{2}{*}{$\mathrm{n}$} & \multicolumn{5}{|c|}{ Carob pod byproduct level (\%) } & \multirow{2}{*}{ SEM } & \multirow{2}{*}{ P-value } \\
\hline & & 0 & 3 & 5 & 10 & 15 & & \\
\hline $\mathrm{EP}(\%)$ & 3 & 73.67 & 72.80 & 72.13 & 74.67 & 73.27 & 27.29 & 0.98 \\
\hline EW (g) & 3 & 12.27 & 12.84 & 12.59 & 12.46 & 13.04 & 0.12 & 0.14 \\
\hline ESW (g) & 3 & 1.84 & 1.90 & 1.73 & 1.68 & 1.72 & 0.00 & 0.09 \\
\hline $\mathrm{ST}(\mathrm{mm})$ & 3 & 0.21 & 0.21 & 0.20 & 0.21 & 0.21 & 0.00 & 0.36 \\
\hline AI (\%) & 3 & 3.56 & 3.64 & 3.42 & 3.48 & 3.31 & 0.02 & 0.16 \\
\hline YI (\%) & 3 & 48.52 & 49.39 & 49.53 & 48.76 & 49.11 & 1.46 & 0.82 \\
\hline ESI (\%) & 3 & 75.93 & 78.19 & 78.20 & 77.14 & 77.48 & 1.95 & 0.31 \\
\hline $\mathrm{CFV}^{1}$ & 3 & 9.40 & 9.07 & 9.35 & 9.23 & 8.75 & 0.16 & 0.34 \\
\hline $\mathrm{HU}$ & 3 & $90.13 \mathrm{a}$ & $90.00 \mathrm{a}$ & $88.17 b$ & $87.93 b$ & $87.90 b$ & 0.83 & 0.02 \\
\hline EYW (g) & 3 & 4.07 & 4.22 & 4.19 & 4.14 & 4.22 & 0.01 & 0.34 \\
\hline EYCF (\%) & 3 & 30.77 & 28.72 & 29.43 & 29.72 & 30.35 & 1.01 & 0.19 \\
\hline EYC (mg) & 3 & 73.64 & 75.15 & 65.22 & 63.11 & 64.41 & 50.00 & 0.18 \\
\hline
\end{tabular}

EP - egg production; EW - egg weight; ESW - egg shell weight; ST - shell thickness; AI - albumen index; YI - yolk index; ESI - egg shape index; CFV - color fan value; HU - Haugh unit; EYW - egg yolk weight; EYCF - egg yolk crude fat; EYC - egg yolk cholesterol; SEM - standard error of the mean.

${ }^{1}$ DSM Nutritional Products.

$\mathrm{a}, \mathrm{b}$ - values with different letters in a row differ significantly $(\mathrm{P}<0.05)$. 
Table 5 - Fatty acid content of egg yolk of Japanese quail fed diets containing different levels of carob pod byproduct

\begin{tabular}{|c|c|c|c|c|c|c|c|c|}
\hline \multirow{2}{*}{ Parameter } & \multirow{2}{*}{$\mathrm{n}$} & \multicolumn{5}{|c|}{ Carob pod byproduct level (\%) } & \multirow{2}{*}{ SEM } & \multirow{2}{*}{ P-value } \\
\hline & & 0 & 3 & 5 & 10 & 15 & & \\
\hline Palmitic acid (C16:0) & 3 & 24.77 & 25.17 & 24.30 & 23.13 & 22.73 & 1.49 & 0.14 \\
\hline Stearic acid (C18:0) & 3 & 8.04 & 8.20 & 7.55 & 8.13 & 7.91 & 0.53 & 0.75 \\
\hline Oleic acid (C18:1) & 3 & 41.32 & 39.61 & 38.91 & 36.49 & 36.30 & 4.97 & 0.08 \\
\hline Linoleic acid (C18:2) & 3 & $17.40 \mathrm{c}$ & $20.69 b c$ & $22.81 \mathrm{ab}$ & $24.37 \mathrm{ab}$ & $26.02 \mathrm{a}$ & 7.18 & 0.05 \\
\hline Gamma linolenic acid (C18:3n6) & 3 & $0.79 \mathrm{c}$ & $1.06 \mathrm{bc}$ & $1.29 \mathrm{ab}$ & $1.52 \mathrm{a}$ & $1.54 \mathrm{a}$ & 0.05 & 0.01 \\
\hline Palmitoleic acid (C16:1) & 3 & $3.06 \mathrm{a}$ & $2.14 \mathrm{~b}$ & $2.16 \mathrm{~b}$ & $1.43 b$ & $1.43 b$ & 0.15 & 0.00 \\
\hline Heptadecanoic acid (C17:0) & 3 & 0.16 & 0.17 & 0.19 & 0.20 & 0.23 & 0.00 & 0.08 \\
\hline Total saturated fatty acids & 3 & $33.53 \mathrm{ab}$ & $32.84 \mathrm{a}$ & $30.68 \mathrm{a}$ & $30.03 b$ & $30.27 b$ & 1.78 & 0.03 \\
\hline Monounsaturated fatty acids & 3 & $45.20 \mathrm{a}$ & $42.61 \mathrm{ab}$ & $42.04 \mathrm{ab}$ & $38.79 b$ & $38.60 \mathrm{~b}$ & 6.17 & 0.04 \\
\hline Polyunsaturated fatty acids & 3 & $18.39 \mathrm{c}$ & $22.05 \mathrm{bc}$ & $24.45 \mathrm{ab}$ & $26.19 \mathrm{ab}$ & $27.89 \mathrm{a}$ & 8.62 & 0.02 \\
\hline Total unsaturated fatty acids & 3 & 63.59 & 64.66 & 66.49 & 64.98 & 66.48 & 3.68 & 0.34 \\
\hline
\end{tabular}

a,b,c - values with different letters in a row differ significantly.

SEM - standard error of the mean.

The gamma linolenic acid (C18:3n6) and total polyunsaturated fatty acid contents of egg yolk increased with increasing CB supplementation ratios in the diets $(\mathrm{P}<0.05)$. The linoleic acid and gamma linolenic acid contents were the lowest in control group and the highest in 15\% CBsupplemented group (Table 5). In the 15\% CB-supplemented group, total polyunsaturated fatty acid contents were higher than in control and in 3\% CB-supplemented groups.

The gamma linolenic acid is promptly elongated into dihomo-gamma-linolenic acid, necessary for production of series 1 prostaglandins (Horrobin, 1992). The linolenic acid obtained from the feed is initially converted into gamma linolenic acid and then to series 1 prostaglandins, which acts as an important anti-inflammatory agent in the body (Sprecher et al., 1995). In addition, the linolenic fatty acid is needed in the body for brain, skin, and bone health functions. Carob pod byproduct supplementation caused an increase in gamma linolenic fatty acid content of egg yolk and, therefore, it may be used to produce functional eggs.

Moreover, the oleic fatty acid ratio of quail eggs was high because of the soy oil, which is a rich source of oleic acid. In a previous study, carob oleic acid (C18:1n9) content was reported as $42.92 \%$ (Gubbuk et al., 2010). It was noted that when soy oil was supplemented in the feed, the egg yolk palmitic, stearic, and oleic fatty acid contents decreased (Sim and Bragg, 1978). The effects of treatments on egg yolk oleic acid content were not significant. Decreasing oleic acid content was observed with increasing $\mathrm{CB}$ and soy oil supplementation ratios.

There was a significant decrease in monounsaturated fatty acids of yolk with increasing level of $\mathrm{CB}$ supplementation (Table 5), despite the rather rich $\mathrm{CB}$ $(45.68 \%)$ in monounsaturated fatty acids, whereas $\mathrm{CB}$ supplementation increased the polyunsaturated fatty acid concentration of yolk. In the current study, polyunsaturated fatty acid concentration of yolk ranged from 18.39 to $27.89 \%$. The concentration of polyunsaturated fatty acid of yolk was considerably higher than that reported by Choi et al. (2001), who found that the polyunsaturated fatty acid concentration of a normal egg was $12 \%$. The differences between the two studies is possibly associated with the differences in chemical composition of diets used in the experiments (Table 5).

The intake of polyunsaturated fatty acid has been reported to reduce the risk of atherosclerosis and coronary heart disease (Lada and Rudel, 2003; Jakobsen et al., 2009). It is well known that foods rich in omega 3 have great benefits for the human health (Mozaffarian and $\mathrm{Wu}, 2011$ ). Therefore, the changes in yolk contents due to $\mathrm{CB}$ supplementation obtained in the present experiment may be important in the nutrition of people with cardiovascular disorders.

\section{Conclusions}

Supplementation of carob byproduct in diets has no detrimental effect on body weight, feed intake, egg internal and external quality traits, and some yolk fatty acid components of laying quail. Therefore, carob byproduct can be used in quail diets up to $15 \%$ as an inexpensive feed source. Supplementation of carob byproduct to quail diets may be an advantage for hyperglycemic poultry. However, the low protein and energy content of carob byproduct should be taken into consideration when included into quail diets.

\section{Acknowledgments}

This study was supported by Directory of Scientific Research Projects, Kahramanmaraş Sutcu Imam University (project no. 2013/2-14YLS). 


\section{References}

Alumot, E.; Nachtomi, E. and Bornstein, S. 2006. Low caloric value of carobs as the possible cause of growth depression in chicks. Journal of the Science of Food and Agriculture 15:259-265.

AOAC - Association of Official Analytical Chemists. 2005. Official methods of analysis. 18th ed. Association Official Analytical Chemists, Gaitherburg, MD, USA.

Avallone, R.; Plessi, M.; Baraldi, M. and Monzani, A. 1997. Determination of chemical composition of carob (Ceratonia siliqua): Protein, fat, carbohydrates, and tannins. Journal of Food Composition and Analysis 10:166-172.

Ayaz, F. A.; Torun, H.; Ayaz, S.; Correia, P. J.; Alaiz, M.; Sanz, C.; Grúz, J. and Strnad, M. 2007. Determination of chemical composition of anatolian carob pod (Ceratonia siliqua): Sugars, amino and organic acids, minerals and phenolic compounds. Journal of Food Quality 30:1040-1055.

Biner, B.; Gubbuk, H.; Karhan, M.; Aksu, M. and Pekmezci, M. 2007. Sugar profiles of the pods of cultivated and wild types of carob bean (Ceratonia siliqua L.) in Turkey. Food Chemistry 100:1453-1455.

Boehringer Mannheim Gmbh Biochemica. 1989. Methods of biochemical analysis and food analysis. Mannheim, Germany. p.26-28.

Choi, S. H.; Song, K. T. and Oh, H. R. 2001. Cholesterol contents and fatty acid composition of chukar, pheasant, guinea fowl and quail egg Yolk. Asian-Australasian Journal of Animal Sciences 14:831-836.

Dubois, M.; Gilles, K. A.; Hamilton, J. K.; Rebers, P. A. and Smith, F. 1956. Colorimetric method for determination of sugars and related substances. Analytical Chemistry 28:350-356.

Göhl, B. 1982. Les aliments du bétail sous les tropiques. FAO, Division de Production et Santé Animale, Roma, Italy.

Gubbuk, H.; Kafkas, E.; Guven, D. and Gunes, E. 2010. Physical and phytochemical profile of wild and domesticated carob (Ceratonia siliqua L.) genotypes. Spanish Journal of Agricultural Research 8:1129-1136.

Hartel, H. 1986. Influence of food input and procedure of determination on metabolizable energy and digestibility of a diet measured with young and adult birds. British Poultry Science 27:11-39.

Horrobin, D. F. 1992. Nutritional and medical importance of gammalinolenic acid. Progress in Lipid Research 31:163-194.

IUPAC - International Union of Pure and Applied Chemistry. 1987. IUPAC standard method 2.507. In: Standart methods for the analysis of oils, fats and derivatives. 7 th ed. IUPAC IID19. The International Union of Pure and Applied Chemistry, Blackwell, Oxford.

Jakobsen, M. U.; O’Reilly, E. J.; Heitmann, B. L.; Pereira, M. A.; Bälter, K.; Fraser, G. E.; Goldbourt, U.; Hallmans, G.; Knekt, P.; Liu, S. and Pietinen, P. 2009. Major types of dietary fat and risk of coronary heart disease: a pooled analysis of 11 cohort studies. The American Journal Clinical Nutrition 89:1425-1432.
Karabulut, A. and Canbolat, Ö. 2005. Yem deðerlendirme ve analiz yöntemleri. Uludað Üniversitesi Yayýnlarý. Yayýn No: 2.05.048.0424, Bursa.

Karabulut, A.; Canbolat, O. and Kamalak, A. 2006. Evaluation of carob, Ceratonia siliqua pods as a feed for sheep. Livestock Research for Rural Development 18(7).

Kotrotsios, N.; Christaki, E. V.; Bonos, E. M. and Florou-Paneri, P. C. 2010. The effect of dietary carob pods on nutrient digestibility in weaning, growing and fattening periods of pigs. Journal of Food Agriculture and Environment 8:779-782.

Lada, A. T. and Rudel, L. L. 2003. Dietary monounsaturated versus polyunsaturated fatty acids: which is really better for protection from coronary heart disease? Current Opinion in Lipidology 14:41-46.

Makris, D. P. and Kefalas, P. 2004. Carob pods (Ceratonia siliqua L.) as a source of polyphenolic antioxidants. Food Technology, Biotechnology 42:105-108.

Mozaffarian, D. and Wu, J. H. 2011. Omega-3 fatty acids and cardiovascular disease: effects on risk factors, molecular pathways, and clinical events. Journal of the American College of Cardiology 58:2047-2067.

NRC - National Research Council. 1994. Nutrient requirements of poultry. 9th ed. The National Academy of Sciences, National Academy Press, Washington, D.C.

Ortiz, L. T.; Rodriguez, M. L.; Alzueta, C.; Rebole, A.; Centeno, C. and Trevino, J. 2004. Effect of carob (Ceratonia siliqua L.) seed in broiler chick diets on nutrient digestibility and intestinal viscosity. p.239-242. In: Recent advances of research in antinutritional factors in legume seeds and oilseeds. Toledo, Spain.

Perez-Olleros, L.; Garcia-Cuevas, M. and Ruiz-Roso, B. 1999. Note. Influence of pulp and natural carob fiber on some aspects of nutritional utilization and cholesterolemia in rats. Food Science and Technology 5:425-430.

Sahle, M.; Coleou, J. and Haas, C. 1992. Carob pod (Ceratonia siliqua) meal in geese diets. British Poultry Science 33:531-541.

Saura-Calixto, F. 1987. Determination of chemical composition of carob pods (Ceratonia siliqua): sugars, tannins, pectins, and amino acids. Anales de Bromatologia 21:81-93.

Silanikove, N.; Landau, S.; Or, D.; Kababya, D.; Bruckental, I. and Nitsan, Z. 2006. Analytical approach and effects of condensed tannins in carob pods (Ceratonia siliqua) on feed intake, digestive and metabolic responses of kids. Livestock Science 99:29-38.

Sim, J. S. and Bragg, D. B. 1978. Effects of dietary oil, cholesterol and soy sterols on the lipid concentration and fatty acid composition of egg yolk, liver and serum of laying hens. Poultry Science 57:466-472.

Sprecher, H.; Luthria, D. L.; Mohammed, B. S. and Baykousheva, S. P. 1995. Reevaluation of the pathways for the biosynthesis of polyunsaturated fatty acids. Journal of Lipid Research $36: 2471-2477$.

Yıldırım, H. and Kaya, Ş. 2011. Karmayeme farklı oranlarda eklenen keçiboynuzu tozunun (Ceratonia siliqua L.) etlik piliçlerin performansına etkisi. Mustafa Kemal Üniversitesi, Ziraat Fakültesi Dergisi 16:43-50. 